(2) In the case of the Sachs-Witebsky we found all positive Sachs are true positives; but all negative Sachs are not true negatives.

(3) We cannot make a definite statement in the case of the micro- and macroM.K.R. as we have done in the Sachs; but we do say, that for such simple tests, the error is very small.

(4) The ordinary Wassermann in our hands has demonstrated one of the points which we set out to prove, viz., that it is not sensitive enough for treated and old-standing cases.

(5) The Mann and Partner Wassermann is, without doubt, the most specific and sensitive of all the tests we have compared and is a decided advance on the No. I Wyler.

We wish to thank Dr. O'C. Donelan, Medical Superintendent, of Grangegorman Mental Hospital, for the interest and support which he has given us in these investigations, also for his permission to quote work done in the hospital laboratory, and for the time he spent in converting certain apparatus to our requirements ; also Dr. Rodgers, Medical Superintendent, of Winwick Mental Hospital, for kindly inviting one of us to his hospital so that we might have first-hand knowledge of the tests being performed; Drs. Nicole and E. J. Fitzgerald for all their trouble in arranging a complete demonstration of the tests on the occasion of our visit, and for their help and advice on the numerous occasions on which we had recourse to them. We would also like to thank them for supplying us with references, etc. in connection with these tests. We wish also to thank the medical staff at Grangegorman and Portrane Mental Hospitals for their co-operation in providing us with material for these tests. Lastly we are indebted to Mr. G. Kennedy, our Laboratory Assistant, for his cheerful and willing help in a labour which added many hours of duty to an already well-filled daily routine.

\title{
THE BOARD OF CONTROL.
}

\section{Committee on Sterilization of Mentally Unfit.}

The Board of Control, with the approval of the Minister of Health, have appointed a Committee with the following terms of reference : To examine and report on the information already available regarding the hereditary transmission and other causes of mental disorder and deficiency ; to consider the value of sterilization as a preventive measure having regard to its physical, psychological and social effects and to the experience of legislation in other countries permitting it ; and to suggest what further inquiries might usefully be undertaken in this connection. The Committee is constituted as follows :-Chairman : L. G. Brock, Esq., C.B., Chairman of the Board of Control ; Wilfred Trotter, Esq., F.R.S., M.D., M.S., F.R.C.S., Member of the Medical Research Council; R. A. Fisher, Esq., Sc.D., F.R.S., F.R.A.S. ; A. F. Tredgold, Esq., M.D., F.R.C.P., M.R.C.S. F.R.S.Ed. ; Miss Ruth Darwin, Commissioner of the Board of Control; E. W. Adams, Esq., O.B.E., M.D., Medical Officer, Ministry of Health ; R. H. Crowley, Esq., M.D., F.R.C.P., Senior Medical Officer, Board of Education; E. O. Lewis, Esq., M.A., D.Sc., M.R.C.S., L.R.C.P., Commissioner of the Board of Control. Mr. F. Chanter of the Board of Control is Secretary of the Committee.

\section{Changes in the Personel of the Board.}

Dr. Arthur Rotherham, Senior Commissioner of the Board, left in October, I93I, on his appointment as Lord Chancellor's Vistor, and Mrs. Ellen F. Pinsent retires on July 3 I, 1932.

The King, on the recommendation of the Minister of Health, has approved the appointment of Dr. W. Rees Thomas, hitherto Medical Superintendent of Rampton State Institution, to be a Senior Commissioner in the place of Dr. Rotherham ; and of Miss Ruth Darwin, formerly an Honorary Commissioner of the Board, and since January I, I93 I, a Commissioner, to be a Senior Commissioner in succession to Mrs. Pinsent. 


\section{Rampton State Institution.}

Dr. F. E. E. Schneider, M.D., M.R.C.S., L.R.C.P., D.P.M., has been appointed Medical Superintendent in succession to Dr. W. Rees Thomas. Mr. J. H. Cobb, M.B., F.R.C.S., has been appointed Honorary Consultant for Diseases of the Ear, Nose and Throat.

\section{PATHOLOGICAL, BACTERIOLOGICAL AND BIOCHEMICAL SUB-COMMITTEE.}

Attention is drawn to the fact that a number of eminent scientific men have agreed to act as Advisers to the Pathological, Bacteriological and Biochemical Sub-committee, and any institution or member of the Association desirous of technical advice in research should communicate with the Honorary Secretary, Dr. F. A. Pickworth, Hollymoor, Northfield, Birmingham.

\section{OBITUARY.}

William Francis Nelis, M.D.Durh., L.R.C.P.Edin., L.R.F.P.S.Glasg.

We regret to record the death, in his 76 th year, of Dr. W. F. Nelis, late Medical Superintendent of the Newport Mental Hospital. He was born in Australia, of Irish parentage; he came to this country to study medicine and proceeded to Anderson College and Glasgow University. He took the Scottish Triple qualification in 1879 , and in 1896 proceeded to the M.D.Durham. After qualifying, he was House Surgeon at the Glasgow Infirmary, and then sailed for a short sea voyage as ship's surgeon. On his return he decided to take up psychiatry as his life's work. He was Medical Officer to the Carmarthen Mental Hospital for a year, and subsequently Assistant Medical Officer at the Monmouthshire Mental Hospital, Abergavenny, for twenty-five years. In 1905 he was appointed Medical Superintendent of the newly erected Newport Mental Hospital at Caerleon. This post be held until his retirement in January, 1929.

The opening of the new Hospital entailed much hard work and foresight, and under his fostering care it grew to maturity. He took the greatest delight and pride in it, earning the confidence of the Committee, who were as zealous as himself in promoting the well-being of the patients under their care. His relations with the patients were of the kindliest; time and custom never dimmed the sympathy he felt for them in their tragic affliction, and his ear was ever ready to listen to their grievances, however trivial.

He had an extensive knowledge of psychiatry, though an innate modesty and shyness prevented him from giving vent to his views in public. He realized that there was a long road yet to travel before the secrets of mental diseases were laid bare, and to this end he thought that the best chances of their elucidation lay in the establishment of coordinated research centres staffed by specialists and supplemented by clinical experience.

Dr. Nelis was under middle height, but in spite of lack of inches, he had a dignified personality; his eyes were keen and shrewd, and he was endowed with common sense and excellent judgment. In addition be was blessed with an extraordinarily retentive memory, which remained unimpaired to the end. He could recall by name patients who had left the hospital many years before, together with their peculiarities.

He had more than a passing acquaintance with botany, and the fine avenue of trees leading from the hospital gates to the main building, with shrubs arranged throughout the grounds (the laying-out of which he personally supervized) is a tribute to his skill as a botanist and to his artistic bent. 